\title{
Lunar cycle and reproductive activity of Redbelly yellowtail fusilier, Caesio cuning in Karimunjawa National Park, Indonesia
}

\author{
FABIAN PANJI AYODYA ${ }^{1, \boldsymbol{v}}$, DIAH PERMATA WIJAYANTI ${ }^{2}$, AGUS SABDONO ${ }^{2}$ \\ ${ }^{1}$ Program of Marine Science, Department of Marine Science, Faculty of Fisheries and Marine Science, Universitas Diponegoro. Jl. Prof. H. Soedarto, S.H., \\ Tembalang, Semarang 50275, Central Java, Indonesia. Tel./fax.: +62-24-7474698, ‘email: fabianpanjiayodya@gmail.com \\ ${ }^{2}$ Department of Marine Science, Faculty of Fisheries and Marine Sciences, Universitas Diponegoro. Jl. Prof. H. Soedarto, S.H. Semarang 50275, Central \\ Java, Indonesia
}

Manuscript received: 5 May 2021. Revision accepted: 30 June 2021.

\begin{abstract}
Ayodya FP, Wijayanti DP, Sabdono A. 2021. Lunar cycle and reproductive activity of Redbelly yellowtail fusilier, Caesio cuning in Karimunjawa National Park, Indonesia. Biodiversitas 22: 3075-3082. Redbelly yellowtail fusilier (Caesio cuning) is known as fish that has been widely distributed among Southeast Asian countries. Fishers in Indonesia especially target the species, causing the scarcity and depletion of the catch in many fisheries areas each year. One of the priority aspects in improving fisheries management in conservation areas is information regarding reproductive activities. Many reports suggested that the lunar cycle affects the reproductive activity of fishes. However, none of the studies reported on the effect of lunar cycle on the reproductive activity of $C$. cuning. This study aimed to explain the lunar cycle effect on the reproductive activity of $C$. cuning through gonadosomatic index (GSI), viscerosomatix index (VSI), and the observation of oocyte conditions. There were 374 individual fishes collected from Nyamuk Island, Karimunjawa from September to November 2020. Samples were taken in each phase and between major phase of the moon (new, first quarter, full, last quarter) during two lunar cycles. The results point out mature gonad (stage IV and V) was present around the new moon. The peak of female GSI occurred around the last quarter moon with figures 6.12 and $5.51 \%$ respectively. The condition of the mature oocyte and ovulation were present around the last quarter and the new moon. The condition indicates imminent spawning.
\end{abstract}

Keywords: Caesio cuning, fusiliers, lunar cycle, reproduction, spawning and synchronization

\section{INTRODUCTION}

Redbelly yellowtail fusilier is a semi-pelagic fish associated with the reefs. The habitat of this species is widely distributed in the Indo-West Pacific (Ackiss et al. 2013). In Indonesia, this species is an economically important fish in the Seribu Islands, where $86 \%$ of the population of the island relies on the fish as their source income (Baum et al. 2016). Setyawan and Yusri (2009) reported the overfishing that occurred on these islands is due to non-selective fishing gear and the raising of fishing effort. This species is also the main targeted fish for compressor fishermen in Karimunjawa (Yuliana et al. 2016). Research from the Jakarta Marine Fisheries Research Institute (BPPL, 2015) shows that from 2008 to 2014 in Natuna waters the production of this species decreased significantly by an average of $26 \%$ each year.

Campbell et al. (2013) explained that the priority aspect to improve fisheries and conservation area management effectiveness is reproductive information. The information mentioned is regarding the spawning time and the factors that influence it, such as the illumination of the moon in each phase (Ikegami et al. 2014). Chakraborty (2018) explained that the fish use the moon as a cue to carry out their biological activities such as behavior at night (Pulver 2017), foraging (Kruse et al. 2016), migration, and reproduction (Shima et al. 2020). The fishermen can also predict the activities and environmental conditions to increase their catch, thus making the fish population even more vulnerable.

Environmental cycles occurred at a different timescale like annual, lunar and daily periodicity. Predictable abiotic and biotic environmental changes are used to maintain time and anticipate recurring events, to optimize the viability of fish populations (Oliveira and Vázquez 2010). Wootton (2015) also explained that environmental factors are closely related to determine the spawning time of fish in their respective natural habitats. Until now, the role of environmental factors in the reproductive activity of Redbelly yellowtail fusiliers that inhabit tropical waters, namely Indonesia is still not yet known widely yet. The study on the reproductive activity of this species is still limited to the spawning season, while the spawning time based on the lunar cycle has never been known (Susilo et al. 2008) and (Prihatiningsih et al. 2018).

Ikegami et al. (2014) explained that the environmental factors and the lunar cycle are used as a cue for many fish to determine their reproductive activity time. Areas with low temperature and lighting period variations, such as the tropics, is relying on the influence of the moon as a signal for marine organisms to carry out these biological activities. Environmental conditions during the lunar cycle always change periodically, such as geomagnetic fields (Bevington, 2015), gravitational pull, tidal amplitude (Neumann 2014) and illumination (Ikegami et al. 2014). Fish uses this environmental change to start reproductive activities as well as gonadal maturation, feeding activities and spawning (Kruse et al. 2016). Maintaining biological 
activity by relying on environmental cues is an important adaptive strategy and is indispensable for fish to increase the success of reproduction and reduce the risk of harm. The reproductive patterns of each species also differ in the length of time and it takes to complete one reproductive cycle by a population in a different area (Shima et al. 2020).

In Marshall Island, $C$. teres is known to utilize the tidal amplitude during the full moon to spawn each month on March-August. (Bell and Colin 1986). In coral reefs around Sesoko and Ou-jima Island, Japan, the groupers, Epinephelus merra, were reported to spawn their gonads during the full moon on May-June. Spawning is triggered by the change of moonlight illumination from new to full moon which will initiate the gonadal development and spawning event (Fukunaga et al. 2019). In the Roviana Lagoon, Western Province, Solomon Islands, The small emperor, Lethrinus obsoletus, spawn around the new moon for a year (Hamilton and Kama 2004).

The gold-lined spine foot, Siganus guttatus inhabiting Okinawan waters, Japan, was reported to spawn from JuneJuly during the first quarter moon which is triggered by changes in illumination levels (Takeuchi et al. 2018). The same species in Karimunjawa Islands is also known to spawn from March-May and September-November during the first quarter moon which is triggered by moonlight (Susilo et al. 2009). The little spinefoot, S. spinus inhabiting coral reef area around Sesoko Island, northern Okinawa spawns from May-July around the new moon (Harahap et al. 2001). The same species in Chuuk Lagoon, Micronesia also spawns from January-March and JulySeptember around the new moon, which is also triggered by the changes of moon illumination levels (Park et al. 2006a).

The pencil-striped rabbitfish, S. doliatus, showed a gonadosomatic index peak and spawn around the first quarter of each month. Observed through changes in ovarian features that occurred repeatedly three times in a phase of the lunar cycle shows that this species has a synchronous pattern in the development of gonads and spawning (Park et al. 2006b). The most recent research on C. cuning conducted by Longnecker et al. (2014), in Papua New Guinea showed that this species has a high gonadosomatic index (GSI) in the new moon phase.

Research on fish spawning and the lunar cycle of $C$. cuning has never been conducted in Indonesian waters, especially Karimunjawa. The study will provide new information in the different tropical areas. In this study, the researcher document the reproductive activity of $C$. cuning based on the lunar cycle and observe whether there is a synchronized pattern of spawning time with the gonadosomatic index (GSI), viscerosomatic index (VSI) and oocyte conditions. Observation was done during two lunar cycles from September to November 2020 in the Karimunjawa Archipelago.

\section{MATERIALS AND METHODS}

\section{Study area}

Samples were taken from the fish landing area. Samples obtained from 16 fishing points located on the coral reef area of Nyamuk, Kembar, Parang, Krakal Besar island, Kapal and Besi reef of the Karimunjawa National Park, Jepara District, Central Java, Indonesia (Figure 1).
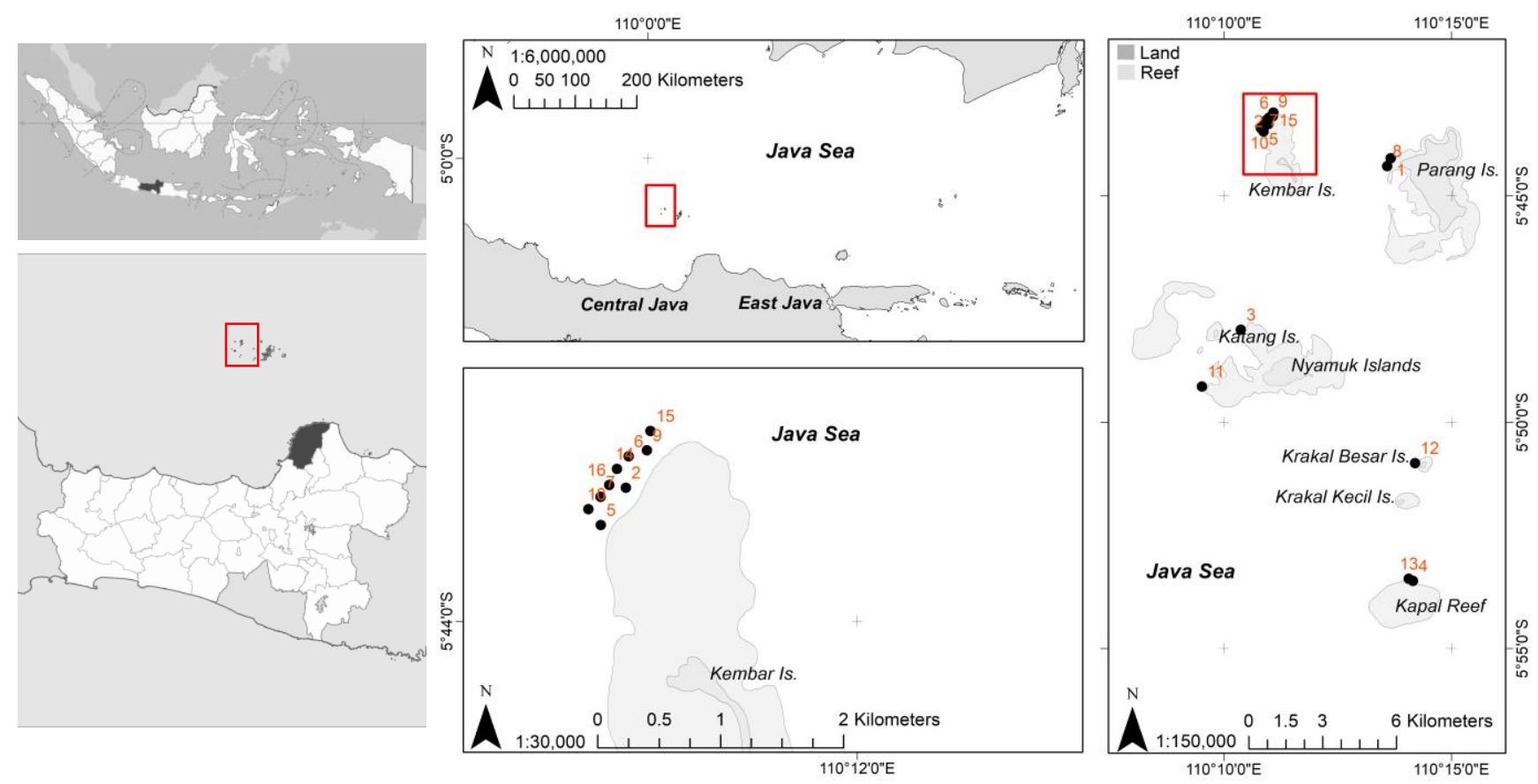

Figure 1. Study sites of sampling location. (Close circle: fishing points, number: time of sampling, red open square: closer view, dark grey: land and bright grey: reef, white: sea) 


\section{Procedures}

\section{Fish collection}

C. cuning were sampled in every four major moon phases (new, first quarter, full, last quarter) and four intermediate moon phases (Int: the middle phase between the major phases of the moon) during two lunar cycle from September to November 2020. Fishes were taken by compressor spearfishers operating at night before the fish brought to fish landing area. The source of the fishing points and samples in each sampling was from the same fishing boat. The fishing point/sampling point was obtained from fishermen by writing the fishing location of $C$. cuning onto a satellite map to obtain the precise coordinate data of each sampling. The number of fish per sampling was 25 . This was the minimum number to ensure a reliable indication of the spawning season or spawning time (Colin et al. 2003). The number of all fish caught is not counted. Selected fish have unwounded belly condition and with a size range of the first maturity in Karimunjawa waters above or close to $20.1 \mathrm{~cm}$ (fork length / FL) (Triyono et al. 2011). Samples were stored in the cool box and then taken to the dissection site. Gonadal samples for observation of the oocyte condition selected based on scooping the morphological differences (size, texture, color, and form) of the female gonad in the second lunar cycle (Al Mahmud et al. 2016).

\section{Data collection}

Lunar phases data of Karimunjawa was obtained from international lunar calendar collected from www.timeanddate.com. The reproductive rhythm of $C$. cuning fish was determined using female gonad maturity level (Prihatiningsih, 2018), GSI (Farmer et al. 2017) and VSI (Davidson et al. 2014). Fishes were dissected and all their belly contents were removed. Female gonads were observed visually to determine the level of maturity according to de los Angeles Maldonado-Amparo et al. (2017) into five levels (Table 2). Clean fish bodies were weighed using a scale $(0.01 \mathrm{~g})$ to determine the eviscerated weight of fish $(\mathrm{Bb})$. The gonads and viscera (gut only) that have been removed were also weighed to determine the gonad weight $(\mathrm{Bg})$ and the viscera/gut weight $(\mathrm{Bv})$.

Table 1. Total samples of $C$. cuning during the study

\begin{tabular}{|c|c|c|c|c|c|c|c|c|c|}
\hline \multirow{2}{*}{$\begin{array}{c}\text { Moon } \\
\text { phases }\end{array}$} & \multirow{2}{*}{ No. } & \multicolumn{3}{|c|}{ Luncar cycle 1} & \multirow{2}{*}{ No. } & \multicolumn{3}{|c|}{ Luncar cycle 2} & \multirow{2}{*}{$\begin{array}{c}\text { Gonadal samples for } \\
\text { observation of the oocyte } \\
\text { condition from females in } 2 \text { nd } \\
\text { lunar cycle }\end{array}$} \\
\hline & & Male & Female & Total & & Male & Female & Total & \\
\hline First quarter & 1. & 18 & 7 & 25 & 9. & 12 & 13 & 25 & 4 \\
\hline Int & 2. & 16 & 9 & 25 & 10. & 15 & 10 & 25 & 3 \\
\hline Full & 3. & 1 & 7 & 8 & 11. & 9 & 7 & 16 & 4 \\
\hline Int & 4. & 15 & 10 & 25 & 12. & 14 & 11 & 25 & 3 \\
\hline Last quarter & 5. & 13 & 12 & 25 & 13. & 12 & 14 & 25 & 5 \\
\hline Int & 6. & 20 & 5 & 25 & 14. & 17 & 8 & 25 & 6 \\
\hline New & 7. & 12 & 13 & 25 & 15. & 15 & 10 & 25 & 5 \\
\hline Int & 8. & 20 & 5 & 25 & 16. & 9 & 16 & 25 & 5 \\
\hline Total & & 115 & 68 & 183 & & 103 & 89 & 192 & 35 \\
\hline
\end{tabular}

Note: Int (intermediate): the middle phase between the major phases of the moon; The number of samples in the full moon cannot be fulfilled due to the difficulty of getting samples from fishermen who do not work during the full moon phase. The sample is obtained by capturing the sample independently

Table 2. Macroscopic characteristics to determine the level of female gonads maturity

\begin{tabular}{ll}
\hline Maturity level & The ovaries are small, light, translucent, slightly pink or glassy. \\
\hline I (Immature) & $\begin{array}{l}\text { Increased size from level I. Ovaries is compact, creamy yellow to light orange color, well vascularized with } \\
\text { small cream-colored eggs, the oocytes cannot be observed with a naked eye. }\end{array}$ \\
II (Developing) & $\begin{array}{l}\text { Ovarian wall looks tight to content, large orange-colored ovaries with dense network of blood capillaries } \\
\text { visible internally, the oocytes can be observed with a naked eye. }\end{array}$ \\
III (Ripening) & $\begin{array}{l}\text { Ovaries are distended and fill most of the body cavity, the vascularization looks more branched and thinner } \\
\text { than in previous ovarian levels. } \\
\text { Ovaries are dark brown with orange tonality in some parts, ovaries are flaccid, elongated and appear bruised or } \\
\text { dark in color. Few residual eggs may be present. }\end{array}$ \\
\hline
\end{tabular}




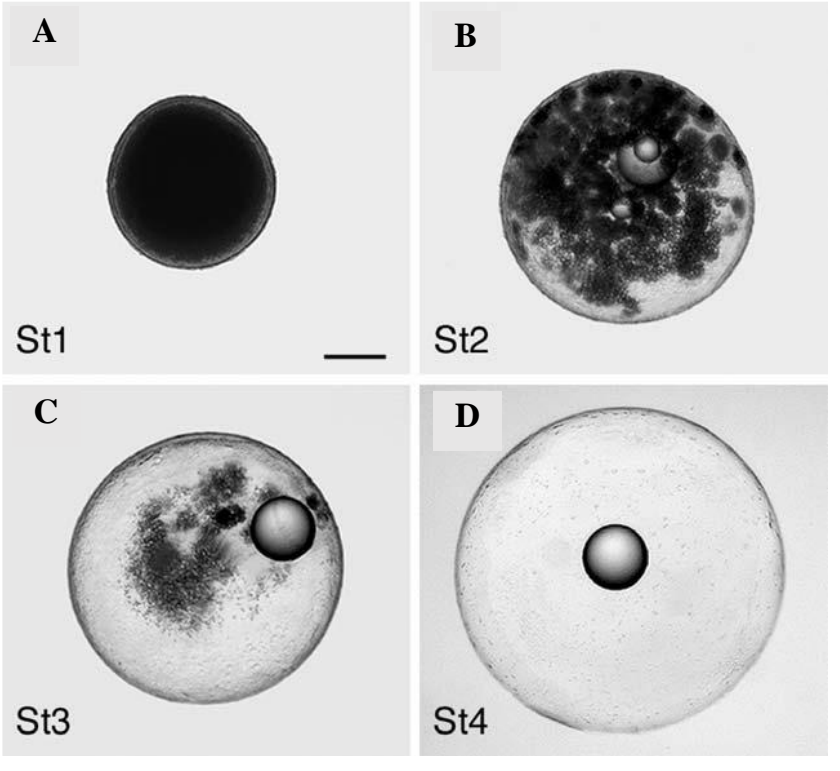

Figure 2. Morphological changes of the pelagophil oocyte gilthead seabream, Sparus aurata, during maturation in vitro. A (St1: Pre-maturation) oocytes with opaque cytoplasm (OpC); B. (St2: Early maturation) oocytes showing more than half of the cytoplasm with the "stippled" appearance (Stp); C. (St3: Late maturation) oocytes showing less than half of the cytoplasm with the "stippled" appearance; D. (St4: Mature) oocytes showing hydrated with a single oil droplet (Od) and translucent cytoplasm (Trc) (The picture used with permission from Fabre et al. 2006)

The oocyte maturation process can be evaluated through several stages as follows: Pre-maturation of the oocyte in stage 1 (St1) is characterized by a smaller oocyte with opaque cytoplasm. At this stage, opaque cytoplasm is caused by yolk globules that are evenly distributed in the cytoplasm (Figure 2.A). The early and late maturation oocytes in stages 2 (St2) and 3 (St3) had a characteristic with stippled cytoplasm (Figure 2.B-C). At this stage, the cytoplasm with the "stippled" appearance continues to disappear due to the yolk globules fusion started. The end result of this process is mature oocytes or stage $4(\mathrm{St} 4)$ where the oocytes had a translucent cytoplasm and a central mass of yolk (Figure 2.D). The changes in size, morphology, and hydration are the result of the yolk globules activities in the oocytes during the maturation process. The presence of (St4) usually coincides with highest GSI value. This stage proves that the condition of the mature oocytes is present during the spawning period (Fabra et al. 2006).

\section{Data analysis}

Gonad maturity level

Diagrams analyzed the level of maturity of the female gonads to observe the composition of each maturity level in each phase of the moon (Prihatiningsih et al. 2018).

Gonadosomatic index

Gonad weight data were analyzed using the gonadosomatic index by following the equation from Farmer et al. (2017) [GSI $\left.=(\mathrm{Bg} / \mathrm{Bb})^{*} 100 \%\right]$, where $\mathrm{Bg}$ is the gonad weight, $\mathrm{Bb}$ is the eviscerated weight. Therefore, the gonad maturation process will be observed quantitatively from this index for each sex.

\section{Viscerosomatic index}

Viscerosomatic index will determine the weight of fish gut in body weight. The VSI calculated with the following formula from Davidson et al. (2014) [VSI= $(\mathrm{Bv} / \mathrm{Bb})^{*} 100 \%$ ], where $\mathrm{Bv}$ is the gut weight, $\mathrm{Bb}$ is the eviscerated weight. The rhythm of feeding activity from $C$. cuning will be observed quantitatively through this index.

\section{Oocyte condition}

Oocyte condition data were analyzed by plotting microscopic photos at each maturity stage during the second cycle of the lunar phase. This photo will represent the oocyte maturation process from each phase in this lunar cycle and observe the present time of mature oocytes and ovulated oocytes to determine spawning time (Fabra et al. 2006 and Al Mahmud et al. 2016).

\section{RESULTS AND DISCUSSION}

\section{Gonad maturity level}

There were 157 dissected females showed a highfrequency maturity in level IV (ripe) and V (spent) around the new moon (Figure 3).

\section{Gonadosomatic index}

There were 217 males and 157 females that were dissected showing the lowest GSI values of females which occurred during full moon on Oct $2(0.83 \%)$ and Oct 31 $(0.97 \%)$. The highest values occurred around the last quarter moon on Oct $13(6.12 \%)$ and Nov $8(5.51 \%)$. The range of GSI value of the male is always lower (0.06 $0.84 \%$ ) compared to the female which has a higher range of GSI values $(0.83-6.12 \%)$ (Figure 4$)$.

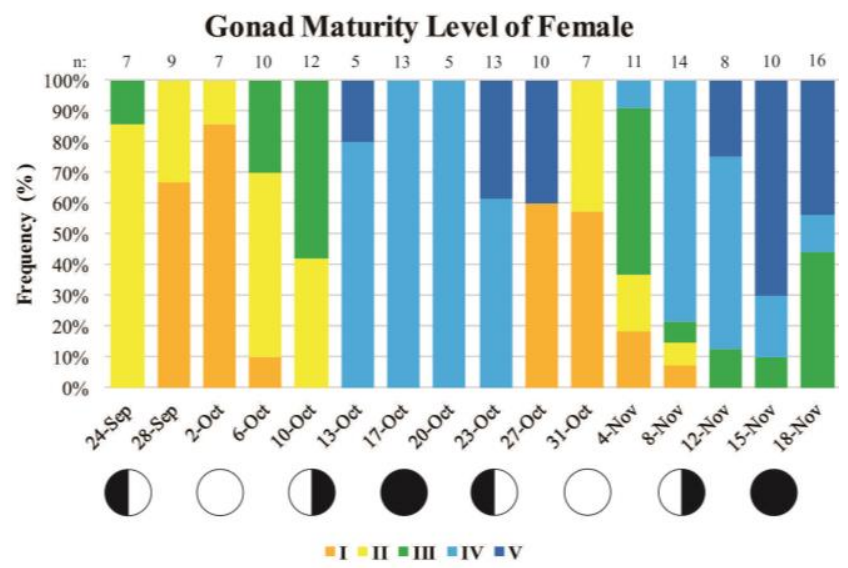

Figure 3. Gonad maturity level of female $C$. cuning during two lunar cycles. Level IV and V were present on Oct 13-27 and Nov 4-18 (14day on both). ( $\mathrm{n}$ : the total sample in each phase of the moon; $\bigcirc$ : first quarter; $\bigcirc$ : full; 1 : last quarter; 0 : new moon phases; level of maturity: I: immature, II: developing, III: ripening, IV: ripe and $\mathbf{V}$ : spent) 


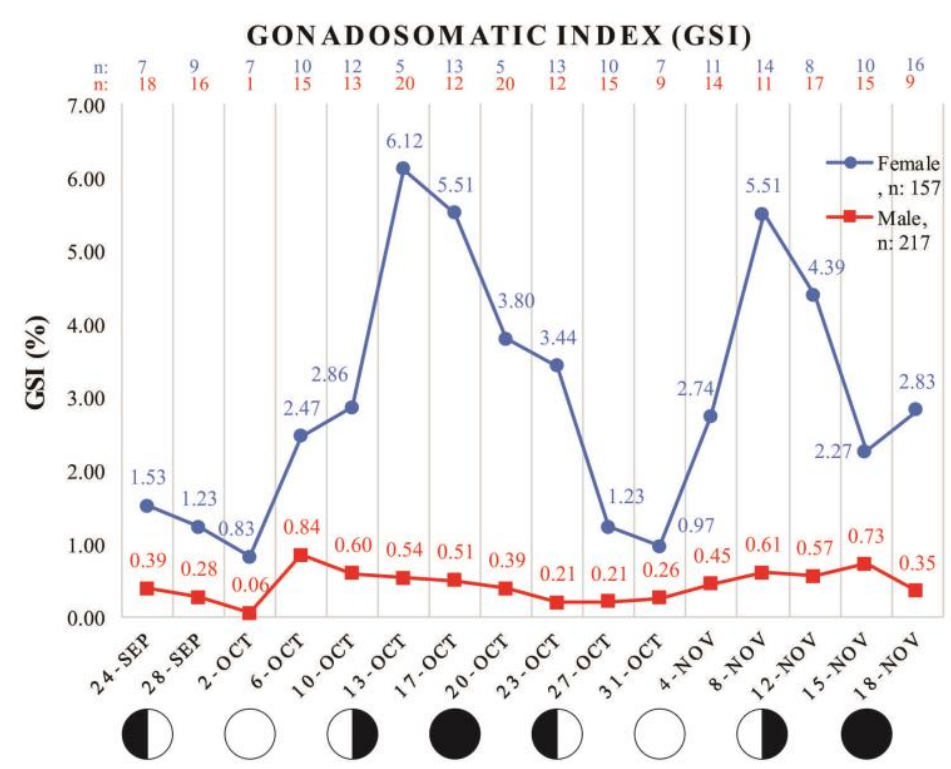

Figure 4. The GSI of male and female $C$. cuning during two lunar cycles. Two periods of increasing GSI occurred in the full moon towards last quarter moon. First period occurred on Oct 2-13 and the second occurred on Oct 31-Nov 8. (n: the total sample in each phase of the moon; $\mathbf{O}$ : first quarter; $\bigcirc$ : full; 1 : last quarter; 0 : new moon phases)

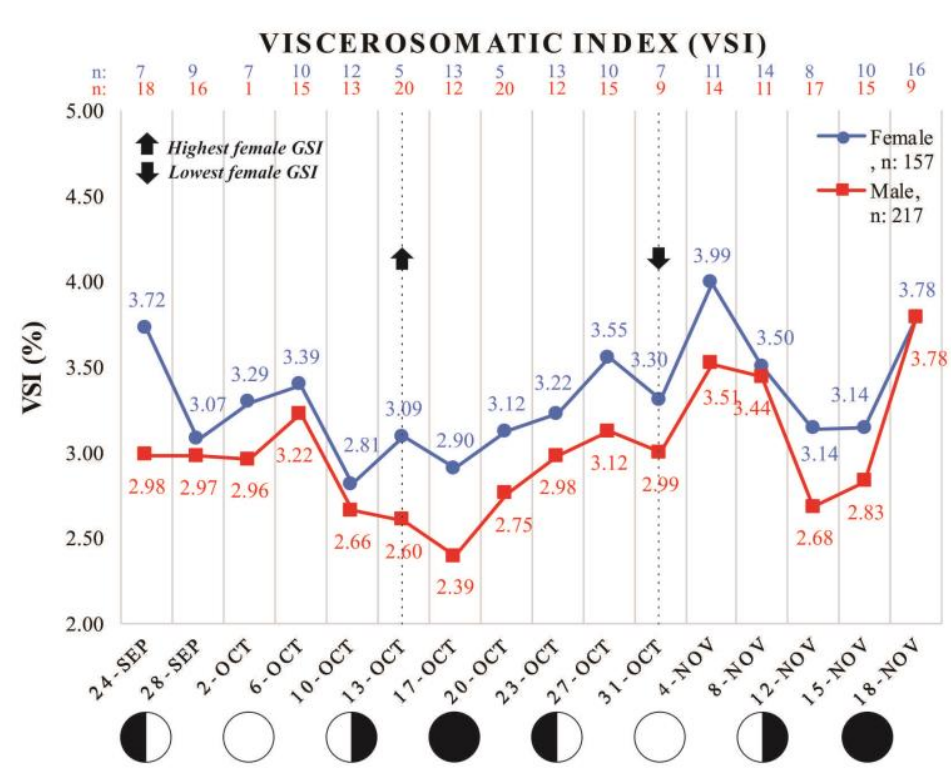

Figure 5. VSI with female highest GSI point index of C. cuning during two lunar cycles. The period of increasing VSI starts around new moon $(17 \mathrm{Oct})$ towards peak in around full moon (4 Nov). This period was followed by a decrease in the highest female GSI value (up arrow; $13 \mathrm{Oct}$ ) toward lowest value (down arrow; $31 \mathrm{Oct}$ ). (n: the total sample in each phase of the moon; $\mathbf{0}$ : first quarter; $\bigcirc$ : full; : last quarter; : new moon phases).

\section{Viscerosomatic index}

From 217 males and 157 females, the female had a higher value than males with an average value of $3.31 \%$ and $2.95 \%$. All of the lowest VSI values occurred around the new moon on Oct 17 and Nov 12, with the male had a value $2.39 \%$ and $2.68 \%$ while the female $2.81 \%$ and $3.14 \%$. The highest VSI values occurred around full moon on Oct 6 and Nov 4, with the male's value of $3.22 \%$ and $3.51 \%$ while the female had $3.09 \%$ and $3.99 \%$, respectively (Figure 5).

\section{Oocyte condition}

From all the female gonad samples during the second lunar cycle, there were 35 samples that showed a difference in size, morphological changes and hydration (Figure 6). The pre-maturation stage (St1) of the oocytes was present in the full moon with most oocytes showing opaque cytoplasm (Figure 6.A). The early maturation stage (St2) of the oocytes was present around the full moon with most of the oocytes showing more than half of the cytoplasm with the "stippled" appearance (Figure 6.B). The late maturation 
stage (St3) of the oocytes was present in the last quarter moon with less than half of the cytoplasm with the "stippled" appearance (Figure 6.C). The mature stage (St4) of the oocyte was present in the new moon with most of the oocytes showing hydrated with a single oil droplet $(\mathrm{Od})$ and translucent cytoplasm (Trc) (Figure 6.D). Oocyte maturation can also be observed through the increasing size of the oocyte.

Oocyte ovulation was observed around the new moon (15 and 18 Nov). The oocyte detached from the ovarian follicle and deposited in the ovarian lumen and oviduct. These oocytes will come out and spread easily when the gonads were cut or removed from the body cavity (Figure 7.A-B). The mature oocyte (mOc) can be seen clearly on the oviduct with translucent characteristics. Most of the immature oocytes (imOc) were still stored in the ovaries and characterized by yellow and orange colors (Figure 7.A). Morphologically, the oocytes character of this species can be classified as pelagophils (eggs that can float in seawater) (Figure 7.C-D).

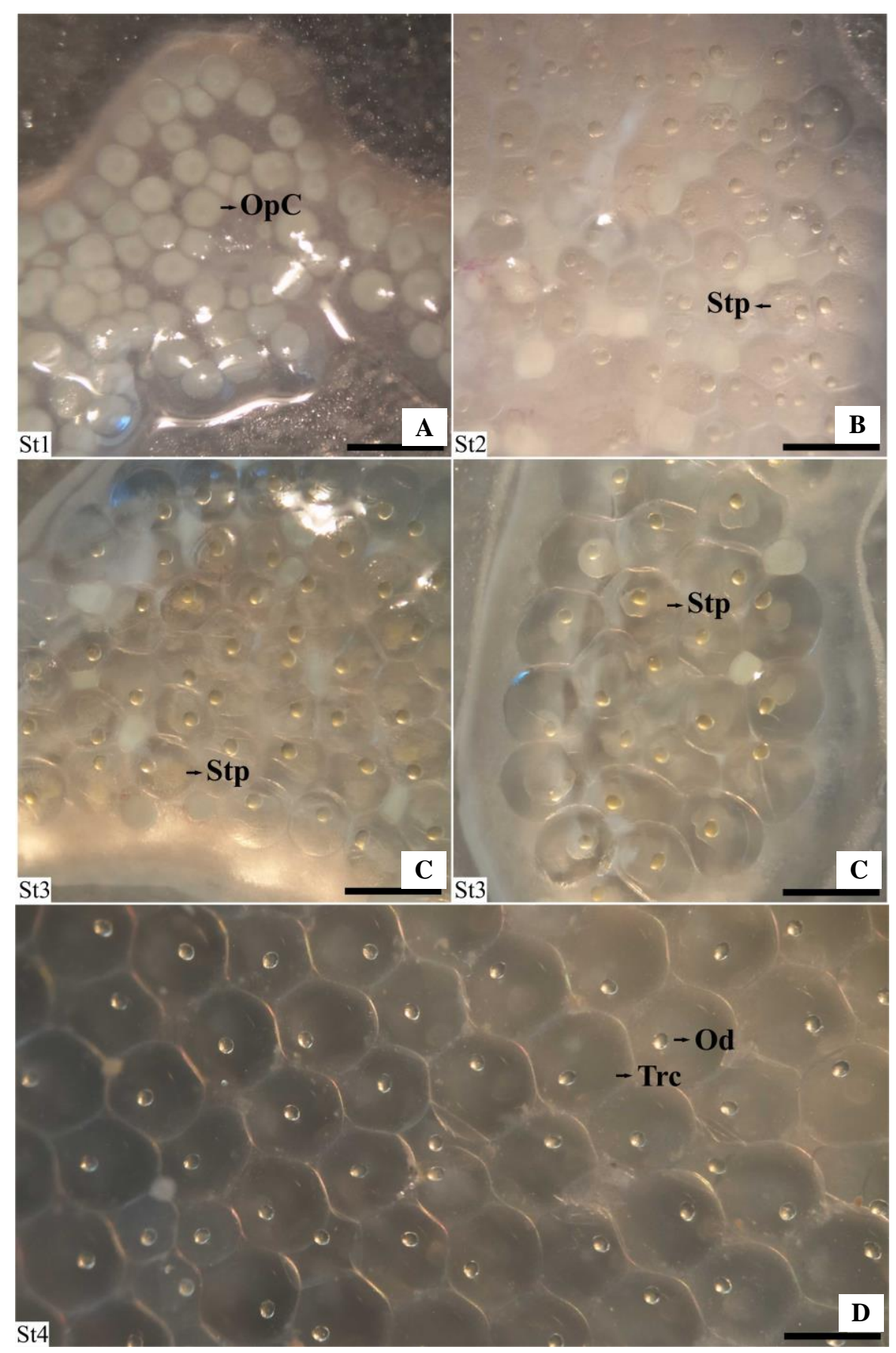

Figure 6. The oocyte maturation process of $C$. cuning in second lunar cycle. A. Pre-maturation oocyte (around full moon, 4 Nov), B. Early maturation oocyte (last quarter moon, $8 \mathrm{Nov}$ ), C. Late maturation oocyte (around last quarter moon, 12 Nov), D. Mature oocyte (new moon, 15 Nov). (OpC) Opaque cytoplasm; (Stp) "Stippled" appearance; (Trc) Translucent; (Od) Single oil droplet; Bar scale: $1 \mathrm{~mm})$ 



Figure 7. Ovulated oocyte from C. cuning observed around the new moon phase (15 and 18 Nov). A. Ovulated oocyte in the oviduct, B. Ovulated oocyte in the ovarian lumen, C. Ovulated oocyte, D. The magnification of the ovulated oocyte with transparent color characteristics with a clearly visible single oil droplet. (Ovr) Ovary; (Ovd) Oviduct; (Ovl) Ovarian lumen; (imOc) Immature oocyte; (mOc) Mature oocyte; (Od) Single oil droplet

\section{Discussion}

The gonad maturity level (Figure 3) shows the ripe and the spent condition that occurred around the new moon. Prihatiningsih et al. (2018) and Dahlan et al. (2018) explained that $C$. cuning which has levels IV and V maturity stage indicates that the gonads were already spawned. These results indicate that $C$. cuning had 14 day spawning period on Oct 13-27 and Nov 4-18. The Spawning events of this species also coincide with the peak spawning season in Karimunjawa waters by Susilo et al. (2009) in October - November. The peak of the spawning season is initiated by the changing of the monsoon and also affected by regional variation of environmental factors such as food abundance, temperature and photoperiod (Takemura et al. 2004).

The close observation of the increase and decrease of GSI values (Figure 4) shows that a mature ovarian occurred when the GSI value is high and vice versa. This rising due to the hydration process that occurs in most oocytes, which is a process of increasing fluid lead the oocytes to enlarge and become heavier, then it will be followed by increasing heavier ovaries and the GSI value. Longenecker et al. (2014) showed that the GSI of $C$. cuning in Papua New Guinea continued to increase during the maturation process where this hydration process occurred, therefore many mature oocytes were found. The completion of the hydration process can be observed by the appearance of the single oil droplet with translucent cytoplasm in each oocyte.

The GSI female (Figure 4) showed that there were 2 peaks in each of the last quarter moon and then dropped significantly after that. The occurrence of these 2 peaks indicates that $C$. cuning is grouped into lunar spawner cycle. Group-synchronous spawners can ovulate many times during each season and was noted by Susilo et al. (2008) that the spawning season of this species occurred in certain months. The lunar spawning cycle is a spawning pattern that follows the rhythm of the moon cycle for 29 days. The lunar spawning cycle is well known in various species. Ohta and Ebisawa (2015) stated that the whitestreaked grouper that live in waters surrounding the Yaeyama Islands, Southwestern most parts of the Ryukyu Archipelago, Okinawa Prefecture, Japan, have a lunar spawning cycle, where the GSI value has been shown to be increased around the full moon phase in two consecutive months. The traditional ecological knowledge from Nyamuk Island fishermen also explained that this species matures eggs every month toward the new moon (Udin 2020, pers. Com.). The difference in the intensity of the moonlight in each phase brought changes in plasma melatonin levels in fish. Plasma melatonin levels during the new moon were higher than the full moon phase. This 
shows that fish can perceive changes in moonlight intensity and melatonin acts as a transducer in aspects of reproductive physiology (Ikegami et al. 2014).

The VSI peak (Figure 5) occurs twice at full moon. The reduction in VSI during spawning was also studied by Hainfellner et al. (2019) in Amazonian planktivorous catfish, Hypophthalmus marginatus. This species continues to feed and increases the VSI to a maximum (3\%) when entering the spawning season, the VSI will decrease. The Rainbow trout, Oncorhynchus mykiss also showed degradation in VSI when entering the spawning period because of the loss of mesenteric fat in the viscera used as energy cost to support gonadal development (Ahongo et al. 2021). Indeed, this period was also followed by a gradual enhancement in the value of the GSI. The two indexes (Figures 4 and 5) in this study also showed the same thing when the GSI starts to increase, VSI will start to fall and vice versa. The highest values of this index indicate that this species increased feeding activity during the full moon and will reduce this activity when it enters the spawning period around the last quarter moon and will repeat the cycle again.

The condition of the oocytes (Figure 6) shows the similarity in size, morphological appearance and hydration of the mature oocyte, although the pre-maturation oocytes were still found in all stages. During the spawning period, ovaries still hold immature oocytes (Figure 7.A). This condition is the type of ovary that group-synchronous spawns had. Wallace and Selman (1981) also revealed that the size of the mature oocyte was uniform but still found another level of oocyte development so it could be categorized as group-synchronous. One of the three ovarian developments is group-synchronous, where at least there was 2 oocytes population that can be found in the ovaries during the reproductive season by observing the domination of one of the oocyte maturity levels.

The ovulated oocyte found in the new moon (Figure 7). These oocytes ovulated from the ovary lamellae (the part of the ovary that plays a role in maturing the oogonia into oocytes). The ovulated oocytes can be observed visually at the ovarian lumen or oviduct (Figure 7A-B). de Mitcheson and Colin (2011) use several criteria as evidence that these fish were spawning, one of them is the presence of hydrated oocytes. This is a very short period before spawning when the body cavity of the fish is tight with mature oocytes. These observations indicate that the fish will be spawning immediately in about 24 hours. Mouchlianitis et al. (2020) also explained that the presence of a hydrated oocyte can be direct evidence that fish will spawn. It means that these fish are group-synchronous spawners because the ovaries retain immature eggs (Figure 7a) and coincide with the concurrent presence of ovulated oocytes (Figure 7.A-C). This indicates that the fish will spawn again in the next cycle during the spawning season.

In conclusion, the study observed that $C$. cuning is a group-synchronous spawner with a lunar spawning cycle and spawning time around the new moon. During gonad development (after spawning), this species increased feeding activity during the full moon in preparation for gonad maturation and spawn in the new moon. This fish is indicated to spawn during the new moon through the presence of a perfectly hydrated oocyte and an ovulated oocyte from the ovary.

\section{ACKNOWLEDGEMENTS}

Authors would like to thank the residents of Nyamuk Island, Karimunjawa who have provided a lot of information to collect the data for the research, namely Musafak, Heru, Aziz, Hor, Udin, Totok, Saane, Robet, and Arif. Special thanks to Mashadi family who have provided logistical support, accommodation, and Mustagfirin who helped collect data during the research.

\section{REFERENCES}

Ackiss, AS, Pardede S, Crandall ED, Ablan-Lagman MCA, Barber PH, Carpenter KE. 2013. Pronounced genetic structure in a highly mobile coral reef fish, Caesio cuning, in the Coral Triangle. Mar Ecol Prog Ser 480: 185-197. DOI: 10.3354/meps10199.

Ahongo, YD, Kerneis T, Goardon L, Labbé L, Bugeon J, Rescan PY, Lefèvre F. 2021. Flesh quality recovery in female rainbow trout (Oncorhynchus mykiss) after spawning. Aquaculture 536: 736290. DOI: $10.1016 /$ j.aquaculture.2020.736290.

Al Mahmud, N, Rahman HMH, Mostakim GM, Khan MGQ, Shahjahan M, Lucky NS, Islam MS. 2016. Cyclic variations of gonad development of an air-breathing fish, Channa striata in the lentic and lotic environments. Fish Aquat Sci 19: 1-7. DOI: 10.1186/s41240016-0005-0.

Balai Penelitian Perikanan Laut. 2015. Pengkajian stok dan optimasi pemanfaatan sumber daya perikanan demersal untuk mendukung industrialisasi di WPP 571- Selat Malaka dan WPP 711 Laut Cina Selatan. Jakarta. [Indonesian]

Bapary MAJ, Amin MN, Takemura A. 2012. Food availability as a possible determinant for initiation and termination of reproductive activity in the tropical damselfish Chrysiptera cyanea. Mar Biol Res 8: 154-162. DOI: 10.1080/17451000.2011.605146.

Baum G, Kusumanti I, Breckwoldt A, Ferse SC, Glaser M, Adrianto, L, Wulp SVD, Kunzmann A. 2016. Under pressure: investigating marine resource-based livelihoods in Jakarta Bay and the Thousand Islands. Mar Pollut Bull 110: 778-789. DOI: 10.1016/j.marpolbul.2016.05.032.

Bell LJ, Colin PL. 1986. Mass spawning of Caesio teres (Pisces: Caesionidae) at Enewetak Atoll, Marshall Islands. Environ Biol Fishes 15: 69-74.

Bevington, M. 2015. Lunar biological effects and the magnetosphere. Pathophysiology 22: 211-222. DOI: 10.1016/j.pathophys.2015.08.005.

Campbell, SJ, Kartawijaya T, Yulianto I, Prasetia R, Clifton J. 2013. Comanagement approaches and incentives improve management effectiveness in the Karimunjawa National Park, Indonesia. Mari Policy 41: 72-79. DOI: 10.1016/j.marpol.2012.12.022.

Chakraborty, U. 2018. Effects of different phases of the lunar month on living organisms. Biol Rhythm Res 2: 254-282. DOI: 10.1080/09291016.2018.1526502.

Dahlan MA, Jannah M, Omar SBA, Nur M. 2018. Aspects of reproductive biology of yellowtail fusilier fish (Caesio cuning Bloch, 1791) in Makassar water. Aquaculture, Aquarium, Conservation \& Legislation 11: 272-277.

Davidson JW, Kenney PB, Manor M, Good CM, Weber GM, Aussanasuwannakul A, Turk PJ, Welsh C, Summerfelt ST. 2014. Growth performance, fillet quality, and reproductive maturity of rainbow trout (Oncorhynchus mykiss) cultured to 5 kilograms within freshwater recirculating systems. J Aquacult Res Dev 5: 4. DOI: 10.4172/2155-9546.1000238.

de los Angeles Maldonado-Amparo M, Sánchez-Cárdenas R, Antonio Salcido-Guevara L, Saúl Ramírez-Pérez J. 2017. Gonadal development of Peprilus medius (Peters, 1869) (Perciformes: Stromateidae) from Southeast of the Gulf of California, Mexico. Intl J Morphol 35: 56-61. 
de Mitcheson YS, Colin PL. 2011. Reef Fish Spawning Aggregations: Biology, Research and Management. Springer Science \& Business Media, New York. DOI: 10.1007/978-94-007-1980-4.

Fabra M, Raldúa D, Bozzo MG, Deen PMT, Lubzens E, Cerdà J. 2006 Yolk proteolysis and aquaporin-1o play essential roles to regulate fish oocyte hydration during meiosis resumption. Dev Biol 295: 50-262. doi:10.1016/j.ydbio.2006.03.034

Farmer NA, Heyman WD, Karnauskas M, Kobara S, Smart TI, Ballenger JC, Reichert MJM, Wyanski DM, Tishler MS, Lindeman KC, Barbieri Susan KL, Switzer TS, Solomon JJ, McCain K, Marhefka M, Sedberry GR. 2017. Timing and locations of reef fish spawning off the southeastern United States. PLoS One 12: e0172968. DOI: 10.1371/journal.pone.0172968.

Fukunaga K, Yamashina F, Ohta N, Mizuno H, Takeuchi Y, Yamauchi C, Takemura A. 2019. Involvement of melatonin in transducing moonrelated signals into the reproductive network of the female honeycomb grouper Epinephelus merra. Gen Compar Endocrinol 282: 113-211. DOI: 10.1016/j.ygcen.2019.113211.

Hainfellner P, Kuradomi RY, de Souza TG, Sato RT, Figueiredo-Ariki DG, Antônio de Freitas G, Luciano Q, Wagner C, Valenti, PMV, Wei G \& Batlouni SR. 2019. Reproductive cycle of the Amazonian planktivorous catfish Hypophthalmus marginatus (Siluriformes, Pimelodidae). Aquacult Res 11: 3382-3391. DOI: 10.1111/are.14296.

Hamilton RJ, Kama W. 2004. Spawning aggregations of coral reef fish in Roviana Lagoon, Western Province, Solomon Islands-A local knowledge field survey report. Report prepared for The Nature Conservancy, Pacific Island Countries Coastal Marine Program.

Harahap AP, Takemura A, Nakamura S, Rahman MS, Takano K. 2001 Histological evidence of lunar-synchronized ovarian development and spawning in the spiny rabbitfish, Siganus spinus (Linnaeus), around the Ryukyus. Fish. Sci 67: 888-893. DOI: 10.1046/j.14442906.2001.00337.x.

Ikegami T, Takeuchi Y, Takemura A. 2014. Lunar clock in fish reproduction. In: Annual, Lunar, and Tidal Clocks. Springer, Tokyo. DOI: $10.1007 / 978-4-431-55261-1$.

Ikegami, T., Takeuchi, Y., Hur, S. P., \& Takemura, A. 2014. Impacts of moonlight on fish reproduction. Mar Genomics 14: 59-66. DOI: 10.1016/j.margen.2013.11.007.

Kruse, M, Taylor M, Muhando CA, Reuter H. 2016. Lunar, diel, and tidal changes in fish assemblages in an East African marine reserve. Reg Stud Mar Sci 3: 49-57. DOI: 10.1016/j.rsma.2015.05.001.

Longenecker K, Langston R, Bolick H, Kondio U. 2014. Rapid reproductive analysis and length-weight relation for red-bellied fusilier, Caesio cuning, and longfin emperor, Lethrinus erythropterus (Actinopterygii: Perciformes: Caesionidae and Lethrinidae) from a remote village in Papua New Guinea. Acta Ichthyologica et Piscatoria 44: 75-84. DOI: 10.3750/AIP2014.44.1.10.

Lubzens, E, Bobe J, Young G, Sullivan CV. 2017. Maternal investment in fish oocytes and eggs: the molecular cargo and its contributions to fertility and early development. Aquaculture 472: 107-143. DOI: 10.1016/j.aquaculture.2016.10.029.

McBride RS, Somarakis S, Fitzhugh GR, Albert A, Yaragina NA, Wuenschel MJ, Alonso-Fernandez A, Basilone G. 2013. Energy acquisition and allocation to egg production in relation to fish reproductive strategies. Fish Fisher 16: 23-57. DOI: 10.1111/faf.12043

Mouchlianitis, FA, Minos G, Ganias K. 2020. Timing of oocyte recruitment within the ovulatory cycle of Macedonian shad, Alosa macedonica, a batch spawning fish with indeterminate fecundity. Theriogenology 146: 31-38. DOI: 10.1016/j.theriogenology.2020.01.050.
Neumann D. 2014. Timing in tidal, semilunar, and lunar rhythms. In: Annual, Lunar, and Tidal Clocks. Springer, Tokyo. DOI: 10.1016/j.margen.2013.11.007.

Ohta, I, Ebisawa A. 2015. Reproductive biology and spawning aggregation fishing of the white-streaked grouper, Epinephelus ongus, associated with seasonal and lunar cycles. Environ Biol Fish 98: 1555-1570. DOI 10.1007/s10641-015-0382-8.

Oliveira C, Vázquez FJS. 2010. Reproduction rhythms in fish. In: Kulczykowska, EW, Kapoor BG (Eds.) Biological clock in fish. CRC Press, Boca Raton, FL. DOI: 10.1201/b10170.

Park YJ, Takemura A, Lee YD. 2006a. Annual and lunar-synchronized ovarian activity in two rabbitfish species in the Chuuk lagoon, Micronesia. Fish Sci 72: 166-172. DOI: 10.1111/j.14442906.2006.01131.x

Park YJ, Takemura A, Lee YD. 2006b. Lunar-synchronized reproductive activity in the pencil-streaked rabbitfish Siganus doliatus in the Chuuk Lagoon, Micronesia. Ichthyol Res 53: 179-181. DOI 10.1007/s10228-005-0322-2.

Prihatiningsih INE, Bambang S. 2018. Biologi Reproduksi, Pertumbuhan dan Mortalitas Ikan Ekor Kuning (Caesio cuning Bloch, 1791) di Perairan Natuna. Bawal 10: 1-15. [Indonesian]

Pulver, JR. 2017. Does the lunar cycle affect reef fish catch rates?. North Am J Fish Manag 37: 536-549. DOI: 10.1080/02755947.2017.1293574.

Rizky, D, Mahardini A, Byun J, Takemura A. 2020. Molecular cloning of insulin-like growth factor 3 (igf3) and its expression in the tissues of a female damselfish, Chrysiptera cyanea, in relation to seasonal and food-manipulated reproduction. Gen Compar Endocrinol 295: 113479. DOI: $10.1016 / j . y g c e n .2020 .113479$.

Setyawan E, Yusri S. 2009. Terumbu Karang Jakarta: Pengamatan Jangka Panjang Terumbu Karang Kepulauan Seribu (2003-2007). Yayasan Terumbu Karang Indonesia, Jakarta. [Indonesian]

Shima, JS, Osenberg CW, Alonzo SH, Noonburg EG, Mitterwallner P, Swearer SE. 2020. Reproductive phenology across the lunar cycle: parental decisions, offspring responses, and consequences for reef fish. Ecology 101: e03086. DOI: 10.1002/ecy.3086.

Susilo ES, Harnadi SL, Takemura A. 2008. Oocyte development and annual cycle of ovarian compositions in the redbelly yellowtail fusilier Caesio cuning (Bloch) from the Karimunjawa Waters. Mar Res Indon 33: 167-173. DOI: 10.14203/mri.v33i2.489.

Susilo ES, Harnadi SL, Takemura, A. 2009. Tropical monsoon environments and the reproductive cycle of the Orange-spotted Spinefoot Siganus guttatus. Mar Biol Res 5: 179-185. DOI: $10.1080 / 17451000802266633$.

Takemura A, Rahman MS, Nakamura S, Park YJ, Takano, K. 2004. Lunar cycles and reproductive activity in reef fishes with particular attention to rabbitfishes. Fish and Fisheries 5: 317-328. DOI: 10.1111/j.14672679.2004.00164.x

Triyono H, Goenawati I, Siswanti NS. 2011. Aspek biologi dan aspek penangkapan Ikan Ekor Kuning (Caesio cuning) yang didaratkan di Pelabuahan Perikanan Pantai Karimunjawa, Kab Jepara, Jawa Tengah. Sekolah Tinggi Perikanan, Jakarta. [Indonesian]

Wallace RA, Selman K 1981. Cellular and dynamic aspects of oocyte growth in teleosts. Amer Zool 21: 325-343.

Wootton RJ, Smith C. 2015. Reproductive Biology of Teleost Fishes. John Wiley \& Sons, Oxford, UK

Yuliana E, Boer M, Fahrudin A, Kamal MM, Muttaqin E. 2016. Status stok ikan karang target di kawasan konservasi Taman Nasional Karimunjawa. Jurnal Penelitian Perikanan Indonesia 22: 9-16. [Indonesian] 